\title{
Identifikasi Kawasan Pertambangan Timah Menggunakan Data Satelit Sentinel - 1 dengan Metode Object Based Image Analysis (OBIA)
}

\author{
Udhi C. Nugroho슬 Dony Kushardono ${ }^{1}$, dan Esthi K. Dewi ${ }^{1}$ \\ ${ }^{1}$ Lembaga Penerbangan dan Antariksa Nasional; e-mail: udhi.catur@lapan.go.id
}

\begin{abstract}
ABSTRAK
Berdasarkan data Pendapatan Nasional Indonesia 2017, sektor pertambangan dan penggalian mempunyai peran penting bagi Indonesia. Sektor ini menyumbangkan 7,57\% pada produk domestik bruto Indonesia di tahun 2017.Salah satu sektor pertambangan yang potensial di Indonesia adalah pertambangan mineral Timah di Pulau Bangka dan Belitung. Namun kegiatan pertambangan ini banyak menimbulkan dampak negatif dari sisi lingkungan. Salah satu upaya awal untuk menanggulangi dampak negatif terhadap lingkungan adalah melakukan identifikasi kawasan pertambangan timah secara spasial. Teknologi yang dapat membantu untuk hal ini salah satunya adalah teknologi penginderaan jauh radar. Penelitian ini menggunakan data satelit radar sentinel-1 yang diluncurkan oleh European Space Agency (ESA). Tujuan penelitian ini adalah pemanfaatan data radar Sentinel-1 untuk identifikasi kawasan pertambangan menggunakan metode Object-Base Image Analysis (OBIA). Data sentinel-1 disegmentasi menggunakan algorithma multiresolution segmentation kemudian di klasifikasi menggunakan algorithma nearest neighbor. Masukan data yang digunakan untuk proses klasifikasi dibuat menjadi dua variasi, yang pertama adalah data standar deviasi, mean, dan brightness pada masing - masing segmen di tiap band, kemudian variasi kedua adalah penambahan data tekstur berupa nilai grey level coocurance matrix (GLCM). Hasil klasifikasi menunjukan bahwa masukan data yang menggunakan data tekstur GLCM mempunyai akurasi lebih tinggi dibandingkan dengan yang tanpa data tekstur GLCM. Secara statistik Hasil klasifikasi dengan tipe satu menunjukan bahwa total akurasi nya adalah sebesar 89,0 \%, dengan nilai kappa sebesar 0,48 sedangkan untuk tipe dua menunjukan bahwa total akurasinya adalah 89,3\%, dengan kappa sebesar 0,50. Hasil klasifikasi kawasan pertambangan dapat digunakan sebagai masukan awal dalam rangka identifikasi spasial kerusakan lingkungan akibat aktivitas pertambangan.
\end{abstract}

Kata kunci: penginderaan jauh, radar, tambang timah, obia, segmentasi, tekstur, grey level coocurance matrix

\begin{abstract}
Based on 2017 Indonesian National Income data, the mining and quarrying sector has an important role for Indonesia. This sector contributes $7.57 \%$ of Indonesia's gross domestic product in 2017. One of the potential mining sectors in Indonesia is tin mineral mining on the islands of Bangka and Belitung. However, many mining activities have negative environmental impacts. One of the initial efforts to overcome the negative impact on the environment was to identify spatial tin mining areas. The technology that can help for this is one of them is radar remote sensing technology. This study uses radar sentinel-1 satellite data launched by the European Space Agency (ESA). The purpose of this study is to use Sentinel-1 radar data to identify mining areas using the Object-Base Image Analysis (OBIA) method. Sentinel-1 data segmented using the multiresolution segmentation algorithm then classified using the nearest neighbor algorithm. The data input used for the classification process is made into two variations, the first is the standard deviation, mean, and brightness data in each segment in each band, then the second variation is the addition of texture data in the form of the gray level coocurance matrix (GLCM). The classification results show that input data using GLCM texture data has a higher accuracy compared to those without GLCM texture data. Statically the classification results with type one show that the total accuracy is $89.0 \%$, with a kappa value of 0.48 while for type two it shows that the total accuracy is $89.3 \%$, with kappa of 0.50 . The results of the classification of the mining area can be used as an initial input in the context of spatial identification of environmental damage due to mining activities.
\end{abstract}

Keywords: remote sensing, radar, tin mining, obia, segmentation, texture, grey level coocurance matrix

Citation: Nugroho, Udhi C., Kushardono, Dony, dan Dewi, Esthi K. (2019). Identifikasi Kawasan Pertambangan Timah Menggunakan Data Satelit Sentinel - 1 dengan Metode Object Based Image Analysis (OBIA). Jurnal Ilmu Lingkungan, 17(1), 140-148, doi: $10.14710 /$ jil.17.1.140-148 


\section{Pendahuluan}

Berdasarkan data Pendapatan Nasional Indonesia 2017, sektor pertambangan dan penggalian mempunyai peran penting bagi Indonesia. Sektor ini menyumbangkan 7,57\% pada produk domestik bruto Indonesia di tahun 2017 (Badan Pusat Statistik, 2017). Tetapi dari sisi lingkungan, sektor ini khususnya pertambangan mineral dan batubara, merupakan penyebab kerusakan lingkungan yang parah dibandingkan kegiatan eksploitasi sumber daya alam lainnya.

Salah satu sektor pertambangan yang potensial di Indonesia adalah pertambangan mineral Timah di Pulau Bangka dan Belitung. Berdasarkan citra drone (pesawat tanpa awak) pada Gambar 1, kawasan pertambangan ditunjukan dengan wilayah yang mempunyai tumpukan tanah dan pasir yang berwarna coklat terang dan putih, kemudian terdapat lubang lubang bekas tambang yang terisi air berwarna coklat, hijau dan biru. Dari citra drone juga menunjukan bahwa kegiatan pertambangan timah mempunyai pola yang tidak teratur. Lubang bekas tambang pada tambang timah oleh penduduk lokal di sebut kolong (Tjhiaw dan Djohan, 2009). Kebanyakan kolong tersebut berisi air yang mempunyai sifat asam dan mengandung logam berat yang berbahaya (Pirwanda dan Pirngadie, 2016). Aktivitas pertambangan ini juga menyebabkan perubahan bentang alam dan kondisi lahan yang tidak mendukung untuk pertumbuhan tanaman (Nurtjahya, 2008).

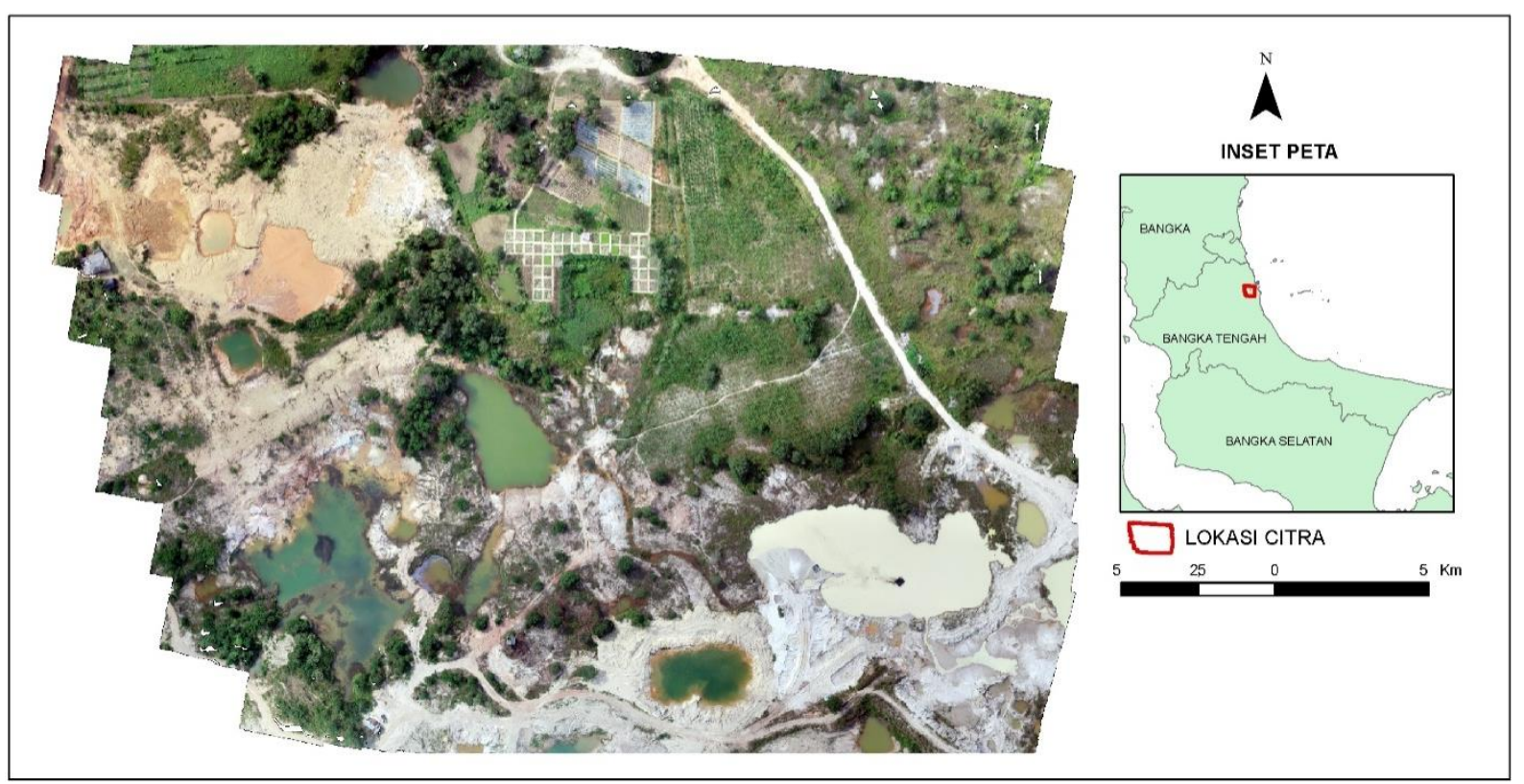

Gambar 1. Kawasan pertambangan timah di potret dari drone

Salah satu upaya awal untuk menanggulangi dampak lingkungan yang diakibatkan oleh aktivitas pertambangan timah adalah melakukan identifikasi kawasan pertambangan timah secara spasial, sehingga didapatkan informasi lokasi dan luas kawasan tersebut. Teknologi yang dapat membantu untuk hal ini salah satunya adalah penginderaan jauh. Penginderaan jauh mempunyai cakupan wilayah yang luas serta ketersedian data yang tetap berlanjut, baik data historis pada masa lampau maupun pada masa sekarang. Data penginderaan jauh yang dapat digunakan adalah citrasatelit optik, citra satelit radar, dan citra hasil pemotretan pesawat tanpa awak ataupun pesawat berawak.

Berdasarkan penelitian yang dilakukan oleh penulis pada tahun 2015, data satelit optik yaitu satelit Landsat - 8 dapat digunakan untuk mengidentifikasi kawasan pertambangan Timah. Metode yang digunakan adalah klasifikasi berbasis piksel dengan algorithmasupervised maximum likelihood yang menghasilkan kelas tambang timah dan bukan tambang timah dengan nilai kappa 0,51. Kendala penggunaan satelit optik adalah tutupan awan yang mengakibatkan terdapat wilayah yang tidak bisa teridentifikasi serta keberadaan bayangan awan yang mengurangi akurasi hasil klasifikasi (Nugroho et al., 2015).

Pemantauan kawasan pertambangan, sebagai salah satu jenis tutupan lahan, menggunakan teknologi penginderaan jauh juga dapat dilakukan tanpa gangguan tutupan awan dengan menggunakan tehnik foto udara dengan pesawat tanpa awak ataupun pesawat berawak (Bamford et al., 2017). Penggunaan wahana pesawat baik yang berawak maupun tanpa awak dibatasi oleh kemampuan cakupan yang tidak terlalu luas, sehingga pemantauan dengan pesawat untuk wilayah yang luasmasih cukup mahal dibanding dengan menggunakan data satelit penginderaan jauh yang juga bisa semakin cepat untuk memperoleh informasi, karena data 
satelit penginderaan jauh semakin banyak tersedia.

Teknologi penginderaan jauh yang digunakan dalam kegiatan ini adalah teknologi satelit radar. Karena kondisi geografis Indonesia yang mempunyai liputan awan yang tinggi menyebabkan banyak lokasi yang sulit teridentifikasi melalui teknologi penginderaan jauh optik karena tertutup oleh awan. Data radar dapat menembus awan karena dikarenakan mempunyai panjang gelombang yang lebih panjang daripada partikel awan (Sutanto, Trisakti, dan Arimurthy, 2014 ;Sutanto et al., 2014).

European Space Agency (ESA) pada tahun 2014 meluncurkan satelit radar Sentinel-1A yang merupakan salah satu satelit konstelasi dua satelit, dimana satelit Sentinel-1B diluncurkan pada tahun 2016. Sentinel -1 membawa sensor radar C-band dengan polarisasi tunggal dan polatisasi ganda. Resolusi temporal dari Sentinel1A adalah 12 hari dengan empat jenis akuisisi yaitu Stripmap (SM), Interferometric Wide Swath (IW), Extra Wide Swath (EW) dan Wave Mode (WV), apabila digabungkan dengan Sentinel-1B resolusi temporalnya bias mencapai 6 hari.

Untuk mendapatkan informasi dari citra penginderaan jauh, terdapat dua metode klasifikasi, yaitu metode klasifikasi pixel based dan klasifikasi object base image analysis (OBIA).Untuk pemantauan objek lahan skala detail, metode klasifikasi digital OBIA dapat diperoleh akurasi hasil yang lebih tinggi dibandingkan dengan metode klasifikasi pixel based (Sari et al., 2014; Zylshal et al., 2016)

Penulis belum menemukan publikasi penelitian tentang pemanfaatan data radar di Indonesia khusus untuk identifikasi kawasan pertambangan, sebagian besar penelitian berupa pemanfaatan data radar untuk identifikasi tutupan lahan secara umum atau biomassa di kawasan reklamasi (Arief et al., 2010; Bainnaura, 2010; Lutfi dan Antono, 2011). Tujuan penelitian ini adalah pemanfaatan data radar Sentinel-1 untuk identifikasi kawasan pertambangan menggunakan metode Object-Base Image Analysis (OBIA).

\section{Metode Penelitian}

Lokasi yang dijadikan obyek penelitian adalah kawasan pertambangan di Kabupaten Bangka Tengah dan Kabupaten Bangka Selatan, Provinsi Kepulauan Bangka Belitung (Gambar 2).Data utama yang digunakan pada penlitian ini adalah data satelit radar Sentinel-1A Level 1 Ground Range DetectedHigh-Res Dual-Pol (GRDHD) dengan tipe akuisisi IW (Interferometric Wide), tanggal akuisisi 13 Maret 2018. Untuk data pendukungnya adalah peta Rupa Bumi Indonesia (RBI) dari Badan Informasi Geospasial yang dapat di unduh di http://tanahair.indonesia.go.id/portal-web.

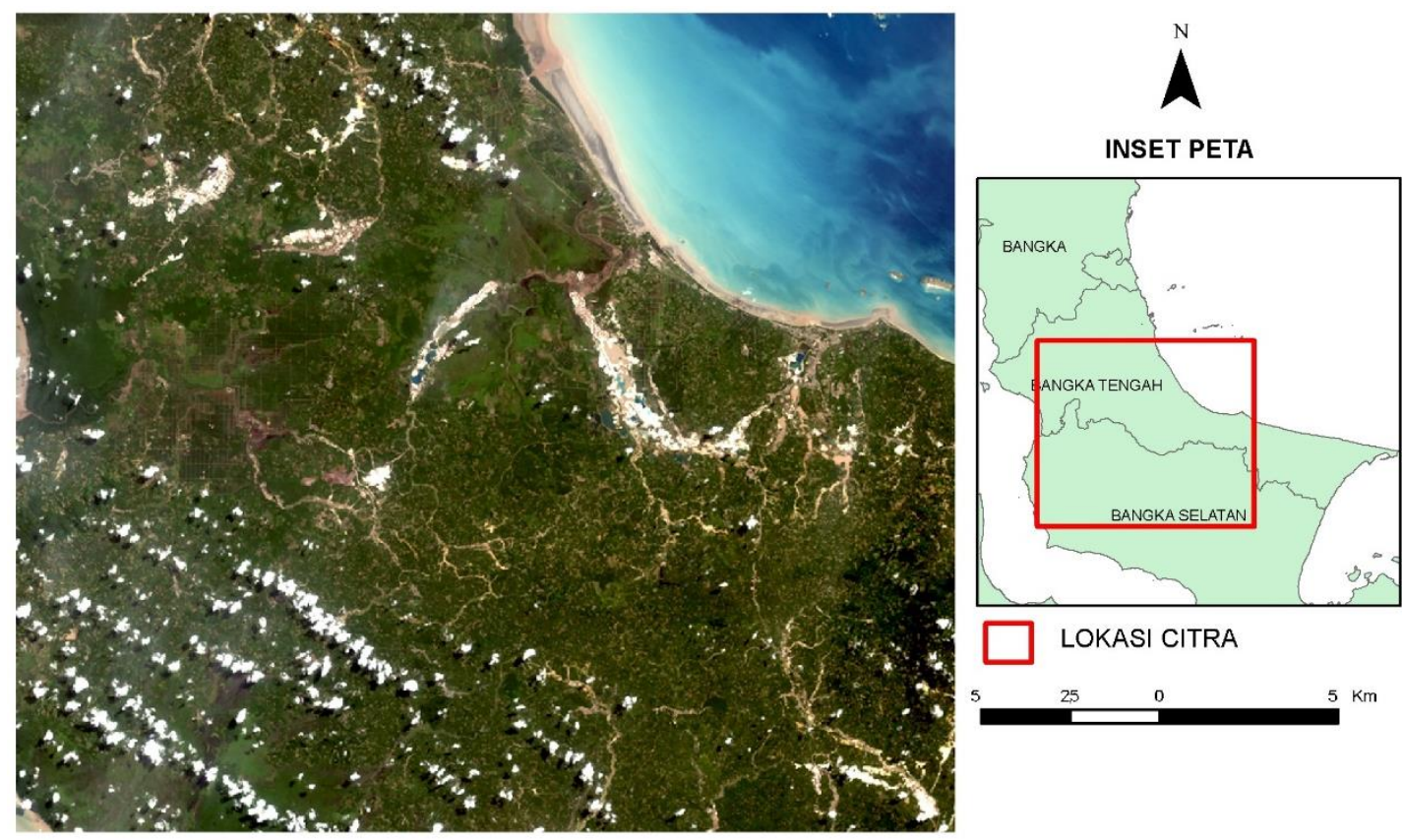

Gambar 2. Lokasi penelitian dilihat dari citra Satelit Landsat - 8

Level data Sentinel -1 Ground Range Detected merupakan data yang telah terdeteksi dan termasuk data multi looking. Data ini telah diproyeksikan dengan jarak permukaan (ground range) dengan menggunakan model elipsoid bumi. Informasi fase pada produk ini hilang dan spickle yang dikurangi karena mengurangi resolusi geometrisnya (ESA, 2013). Karakteristik tipe akuisisi IW memiliki cakupan $250 \mathrm{~km}$ dengan resolusi spasial $5 \mathrm{~m} \times 20 \mathrm{~m}$ (single look). Mode IW mengakuisisi 3 sub-petak dengan menggunakan TOPSAR (Terrain Observation with Progressive Scan SAR).Mode TOPSAR dimaksudkan untuk menggantikan mode ScanSAR konvensional 
dengan cakupan dan resolusi yang sama akan tetapi rasio noise menjadi kecil. Teknologi ini memiliki kelebihan yang dapat menghasilkan kualitas gambar yang homogen dengan noise yang dapat diminimalisir (Signal-to-Noise Ratio) (Emiyati, Manoppo, dan Hartuti, 2016). Karakteristik data Sentinel-1 secara detail dapat dilihat pada Tabel 1.

Langkah awal pengolahan data adalah pre-processing databerupa terrain correctionuntuk mengurangi efek permukaan bumi dan mengkoreksi posisi citra sesuai dengan koordinat di bumi. Data yang diperoleh pada data satelit Sentinel-1 berupa data amplitudo dan intensitas dalam bentuk angka digital. Dari data tersebut dilakukan kalibrasi sehingga didapatkan nilai hamburan balik dalam sigma naught $\left(\sigma^{0}\right)$ dengan menggunakan persamaan berikut (Cazals, et al., 2016; Miranda dan Meadows, 2015),

$$
\sigma^{0}[d B]=10 * \log _{10}\left(\frac{D N^{2}}{A_{d n}^{2} K} \sin (\alpha)\right)
$$

dimana $\sigma^{0}$ adalah koefisien hamburan balik $(\mathrm{dB})$, $\mathrm{K}$ adalah koefisien kalibrasi, DN adalah digital number, $\alpha$ adalah insidince angle, dan $\mathrm{A}$ adalah amplitude.Data citra yang dihasilkan dari proses pre-processing digunakan sebagai input untuk proses Object-Base Image Analysis (OBIA) dan klasifikasi digital nearest neighbor menggunakan software Ecogniton.

Tabel 1. Karakteristik utama data Sentinel-1 tipe akuisisi IW

\begin{tabular}{cc}
\hline \hline Karakteristik & Nilai \\
\hline Width Swath & $250 \mathrm{~km}$ \\
Interval insiden angel & $29.10^{\circ}-46.0^{\circ}$ \\
Elevation beem & 3 \\
Azimuth steering angle & $\pm 0.6^{\circ}$ \\
Azimuth and range looks & Single
\end{tabular}

Polarization Options

Dual $H H+H V, V V+V H$. Single $H H, V V$

Maximum NESZ

$-22 d B$

Radiometric stability

$0.5 d B$

Radiometric accuracy

$1 d B$

Phases error

$5^{\circ}$

Sumber: Eropean Space Agency, 2013

a. Object-Base Image Analysis (OBIA)

Metode OBIA merupakan salah satu metode baru dalam klasifkasi citra (Navulur, 2007).

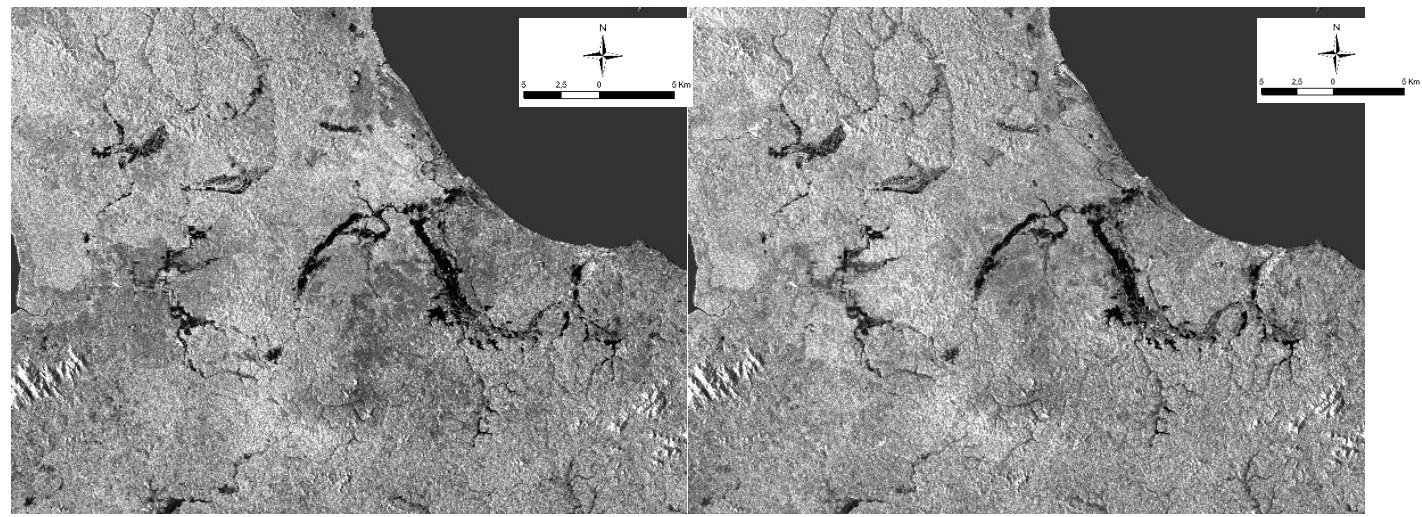

(a)

(b)

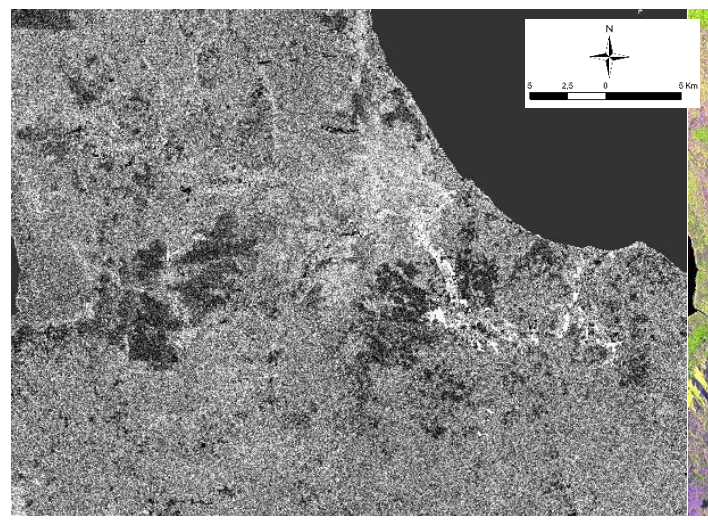

(c)

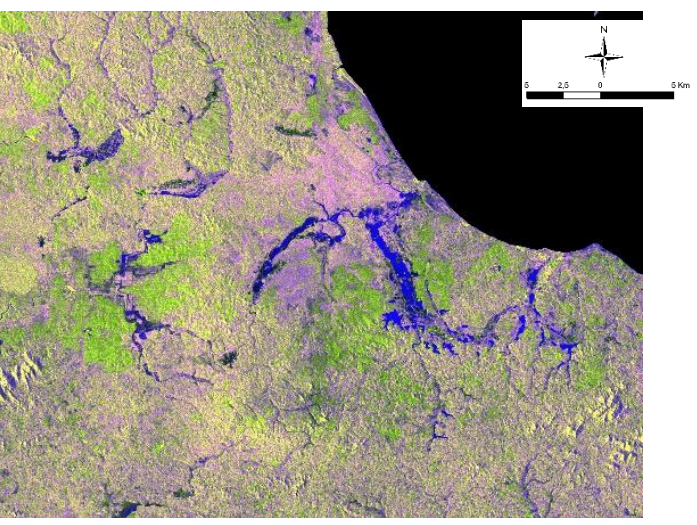

(d)

Gambar 3. (a) Citra polarisasi VH (b) Citra polarisasi VV (c) Citra Natural Difference Polarisation Index (NDPI) (d) Komposit RGB (VH, VV, NDPI) 
Metode klasifkasi ini menggunakan proses segmentasi dan penggunaan sistem hirarki (Blaschke, 2010).Secara sederhana, OBIA adalah proses segmentasi citra menjadisegmen/objek yang homogen sesuai dengan parameternya. Pendekatan OBIA dinilai lebihunggul dari klasifikasi berbasis pikselkarena tidak hanyamempertimbangkan aspek spectral tetapi juga spasial (Wibowo, 2012).Pada penelitian ini, metode segmentasi yang digunakan adalah multiresolution segmentation (MSR). Skala parameter yang digunakan dalam proses segmentasi adalah 50, kemudian nilai shape yang digunakan adalah 0,7 dan nilai compactness adalah 0,3 .

Sebagai masukan dalam proses segmentasi adalah data citra hasil pre-processing yang disusun dengan kombinasi RGB berupa VH, VV, dan NDPI (Normalized Difference Polarization Index) (Kushardono, 2012). NDPI digunakan sebagai false image agar terbentuk komposisi RGB sehingga tampilan citra bisa lebih jelas dan berwarna (Gambar 3). NDPI didapatkan dengan persamaan berikut :

$$
\text { NDPI : (VH -VV) / (VH + VV) }
$$

\section{b. Nearerst-Neighbour Classification}

Algoritma nearest neighbor merupakan metode klasifikasi terbimbing yang bertujuan untuk mengklasifikasikan obyek berdasarkan atribut dan training sample. Algorithma nearest neighbor menggunakan klasifikasi ketetanggan sebagai prediksi dari training sample. Algorithma ini menentukan nilai jarak pada testing data dengantraining data berdasarkan nilai terkecil dan nilai ketetanggaan terdekat (Gan, et all., 2007)

$$
d_{i}=\sqrt{\sum_{i=1}^{p}\left(x_{2 i}-x_{1 i}\right)^{2}}
$$

dimana $x 1$ adalah sampel data, $x 2$ adalah data uji, $i$ adalah variable data, dan $d$ adalah jarak

Di dalam penelitian ini, data masukan dalam proses klasifikasi dibuat menjadi dua variasi, yang pertama adalah menggunakn data standar deviasi, mean, dan brightness pada masing - masing segmen di tiap band, kemudian variasi kedua adalah penambahan data tekstur berupa nilai Grey Level Coocurance Matrix (GLCM). GLCM merupakan salah satu metode untuk memperoleh ciri statistik orde dua dengan cara menghitung probabilitas hubungan ketetanggaan antara dua piksel pada jarak dan orientasi sudut tertentu (Albregtsen, 2008). Pendekatan proses GLCM bekerja dengan membentuk sebuah matriks kookurensi data citra, dilanjutkan dengan menentukan ciri sebagai fungsi dari matriks antara tersebut (Kasim dan Harjoko, 2014). Nilai pada tiap elemen matriks kookurensi adalah $\mathrm{P}(i, j)$ di mana nilai tersebut merupakan peluang kejadian nilai digital $i$ bertemu dengan nilai digital j. Dari nilai peluang tersebut dapat dihasilkan fitur tekstur yang diformulasikan oleh Haralick, 1985 sebagai berikut,

a. Angular second moment

b. Contrast

$$
\sum_{i, j}\{P(i, j)\}^{2}
$$

$$
\sum_{i, j}(i-j)^{2} P(i, j)
$$

c. Homogenity

d. Entropy

$$
\sum_{i, j}(i-j)^{2} \log P(i, j)
$$

e. Dissimilarity

$$
\sum_{i, j} P(i, j) \log P(i, j)
$$

$$
\sum_{i, j} P(i, j)|i-j|
$$

\section{f. Correlation}

g. Mean

$$
\sum_{i, j}\left\{(i, j) P(i, j)-\mu_{x} \mu_{y}\right\} / \sigma_{x} \sigma_{y}
$$

$$
\sum_{i, j} i . P(i, j)
$$

h. Variance

$$
\sum_{i, j} P(i, j)\left(i-\mu_{i}\right)^{2}
$$

Keterangan, $\mu_{x} \mu_{y}$ adalah rataan dan $\sigma_{x} \sigma_{y}$ adalah standar deviasi

Ukuran window matriks menggunakan nilai yang ditentukan oleh software Ecognition dan tidak bisa dirubah yaitu 256 x 256, sedangkan orientasi sudut yang digunakan adalah semua semua sudut piksel tetangga.

Hasil klasifikasi menggunakan algorithma nearest neighbor di uji akurasi menggunakan metode confussion matrix. Yang akan dijadikan sebagai referensi adalah peta lahan akses terbuka tambang (LAT) yang dikeluarkan oleh Kementerian Lingkungan Hidup dan Kehutanan hasil kerjasama dengan Pusat Pemanfaatan Penginderaan Jauh LAPAN. Peta ini dihasilkan melalui digitasi manual dengan data citra satelit Landsat -8.

\section{Hasil dan Pembahasan}

Proses segmentasi yang dilakukan menggunakan software Ecognition dengan penentuan skala parameter berdasarkan tingkat 
kedetailan obyek yang ingin dihasilkan. Semakin kecil nilai skala, maka obyek yang dihasilkan akan semakin detail. Penulis menggunakan skala 50 karena obyek kawasan pertambangan bukan merupakan obyek tunggal melainkan kawasan yang terdiri dari beberapa sub-obyek, yaitu tubuh air di kawasan tambang, vegetasi, dan lahan terbuka. Selain itu untuk pembangun homogenitas obyek digunakan kriteria yang berasal dari bentuk (shape) dan kekompakkan (compactness) yang dinyatakan dengan kontribusi optimum sehingga diperoleh segmentasi objek yang sesuai. Semakin kecil nilai shape maka pengaruh bentuk semakin kecil dalam penentuan obyek atau pengaruh warna semakin besar dan semakin kecil nilai compactness maka obyek yang akan dikelaskan semakin kompak. Obyek kawasan pertambangan timah mempunya variasi warna yang tinggi dan mempunyai pola yang khas, yaitu menjari mengikuti pola aliran air maka untuk mengidentifikasikannya, skala shape yang digunakan tinggi yaitu 0,7 dan skala compactness yang digunakan rendah yaitu 0,3.Pada saat ini belum ditetapkan penggunaan teoritis yang baku terhadap penggunaan segmentasi terbaik sehingga pengguna harus mencari sendiri untuk menentukan parameter segmentasi terbaik pada setiap level melalui try and error (Blaschke \& Hay 2001; Burnett \& Blaschke 2003).Proses segmentasi menghasilkan 5.730 segmen dari total luas daratan pada citra yang di proses sebesar 95.229,8 Ha dengan luas segmen terkecil adalah 0,06 Ha dan luas segmen terbesar adalah 113,599 Ha (Gambar 4).

Tabel 2. Confussioon matrixhasil Klasifikasi menggunakan input tipe satu

\begin{tabular}{lcr}
\multicolumn{3}{c}{ menggunakan input tipe satu } \\
\hline \hline & Tambang LAT & $\begin{array}{c}\text { Non Tambang } \\
\text { LAT }\end{array}$ \\
\hline $\begin{array}{l}\text { Tambang } \\
\text { klasifikasi }\end{array}$ & 6240,2 & 5491,9 \\
$\begin{array}{l}\text { Non } \\
\text { Tambang } \\
\text { klasifikasi }\end{array}$ & 4956,3 & 78541,4 \\
$\begin{array}{l}\text { Total } \\
\text { Akurasi }\end{array}$ & $89,0 \%$ & \\
Nilai & & \\
Kappa & 0,48 & \\
\hline
\end{tabular}

Tabel 3. Confussioon matrixhasil Klasifikasi menggunakan input tipe dua

\begin{tabular}{lrr}
\hline \multicolumn{3}{c}{ menggunakan input tipe dua } \\
\hline & Tambang LAT & $\begin{array}{c}\text { Non Tambang } \\
\text { LAT }\end{array}$ \\
\hline $\begin{array}{l}\text { Tambang } \\
\text { klasifikasi }\end{array}$ & 6632,5 & 5620,2 \\
$\begin{array}{l}\text { Non } \\
\text { Tambang } \\
\text { klasifikasi }\end{array}$ & 4563,9 & 78413,1 \\
Total & & \\
$\begin{array}{l}\text { Akurasi } \\
\text { Nilai Kappa }\end{array}$ & $89,3 \%$ & \\
\hline
\end{tabular}

Proses klasifikasi yang dijalankan sudah tidak berdasarkan nilai piksel lagi tapi berdasarkan nilai statistic tiap segmen yang dihasilkan pada proses segmentasi, pendekatan ini disebut dengan object base image analysis. Pada penelitian ini dilakukan dua tipe masukan klasifikasi, pada tipesatu masukan yang dipakai adalah nilai rata - rata (mean) hamburan dalam satu segmen, standard deviasi dalam satu segmen, dan brightness, sedangkan pada tipedua terdapat penambahan fitur GLCM .

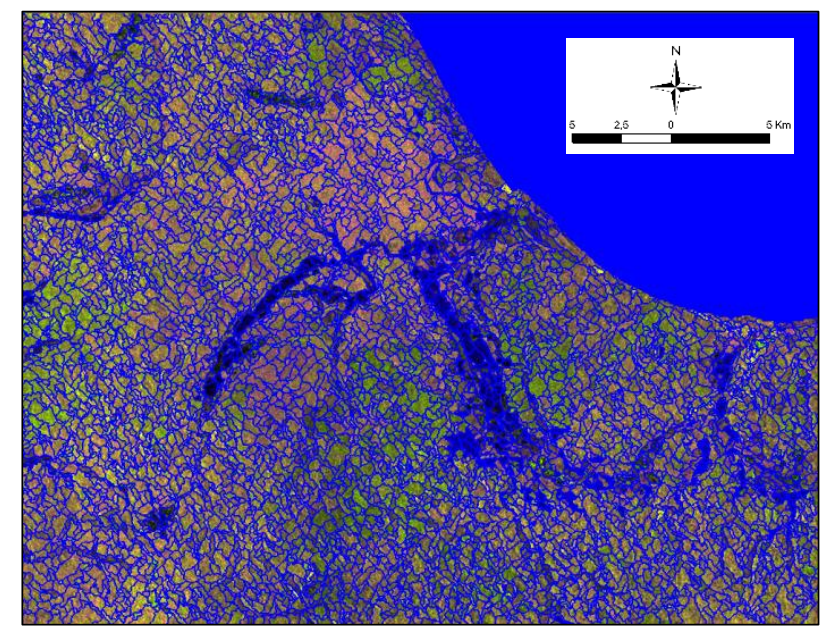

Gambar 4. Hasil proses segmentasi multiresolution

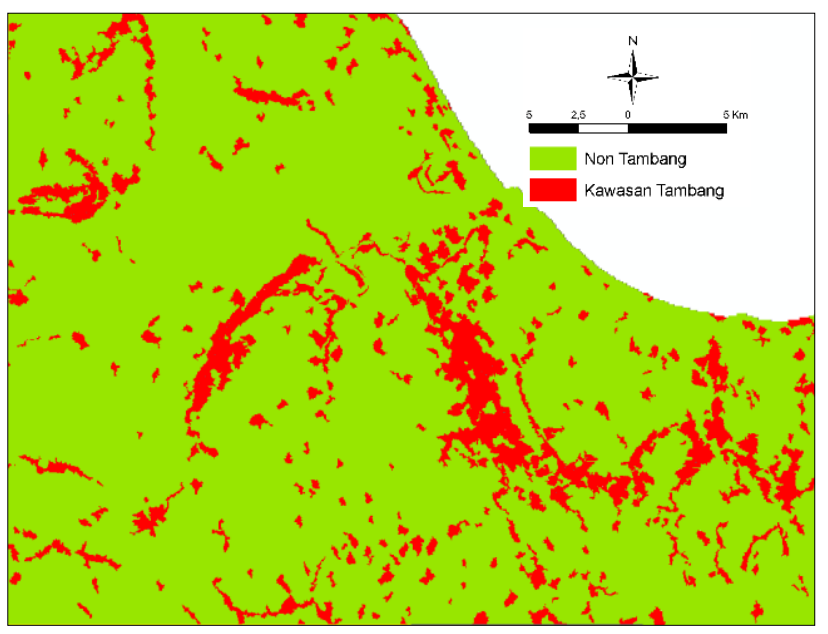

(a)

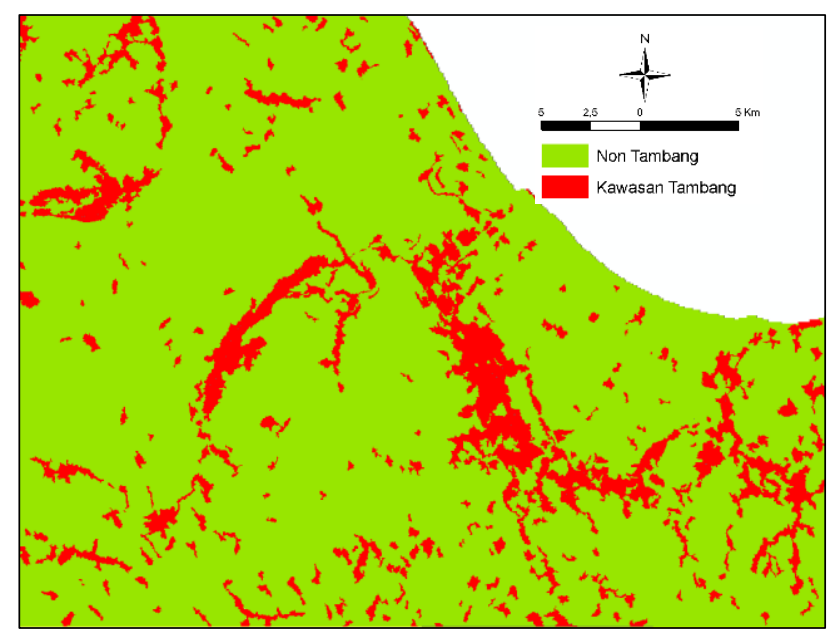

(b)

Gambar 5. (a). Hasil klasifikasi menggunakan input tipe satu (b) Hasil klasifikasi menggunakan input tipe dua 
Hasil klasifikasi dengan tipe satu(Gambar 5a) menunjukan bahwa total akurasi nya adalah sebesar $89,0 \%$, dengan nilai kappa sebesar 0,48 (Tabel 2) sedangkan untuk tipe dua (Gambar 5b) menunjukan bahwa total akurasinya adalah 89,3\%, dengan kappa sebesar 0,50 (Tabel 3). Secara keseluruhan hasil yang didapatkan pada klasifikasi tipe satu dan tipe dua mempunyai akurasi yang tinggi.Berdasarkankesepakatan yang dikeluarkanoleh Badan Survei Geologi Amerika Serikat (USGS) yaitu telah memberikan syarat untuktingkat ketelitian/akurasi sebagai kriteria utama bagisistem klasifikasi penutupan lahan yang disusun.Tingkat ketelitian klasifikasi minimum denganmenggunakan penginderaan jauh harus tidakkurang dari 85\% (Affan et all., 2010). Nilai kappa kedua hasil klasifikasi secara kualitatif termasuk dalam kelompok moderate atau cukup (Tabel 4).

Hasil klasifikasi belum dapat mendapatkan nilai kappa yang tinggi karena user's accuracykelas tambang hanya $53,1 \%$ untuk hasil klasifikasi tipesatu dan 54,1 \% untuk hasil klasifikasi tipe dua, nilai ini berbanding terbalik dengan user's accuracy kelas non tambang yaitu sebesar 94,1\% untuk klasifikasi tipe satu dan 94,5\% untuk klasifikasi tipedua. Nilai user's accuracy yang tidak tinggi pada kelas tambang menunjukan bahwa masih banyak kesalahan klasifikasi kawasan pertambangan timah yang pada data referensi bukan merupakan kawasan pertambangan timah. Hasil klasifikasi pada kedua tipe menunjukan nilai yang over estimate pada kelas kawasan tambang. Padapembahasan selanjutnya akan digunakan hasil klasifikasi yang menggunakan masukan tipe dua karena secara akurasi lebih tinggi daripada yang tipe kedua.

Tabel 4. Keterangan kualitatif nilai kappa

\begin{tabular}{ll}
\hline \hline Kappa & Keterangan Kesamaan \\
\hline$<0.20$ & Rendah (Poor) \\
$0.21-0.40$ & Lumayan (Fair) \\
$0.41-0.60$ & Cukup (Moderate) \\
$0.61-0.80$ & Kuat (Good) \\
$0.81-1$ & Sangat Kuat (Very Godd) \\
\hline
\end{tabular}

Sumber: Altman, 1991

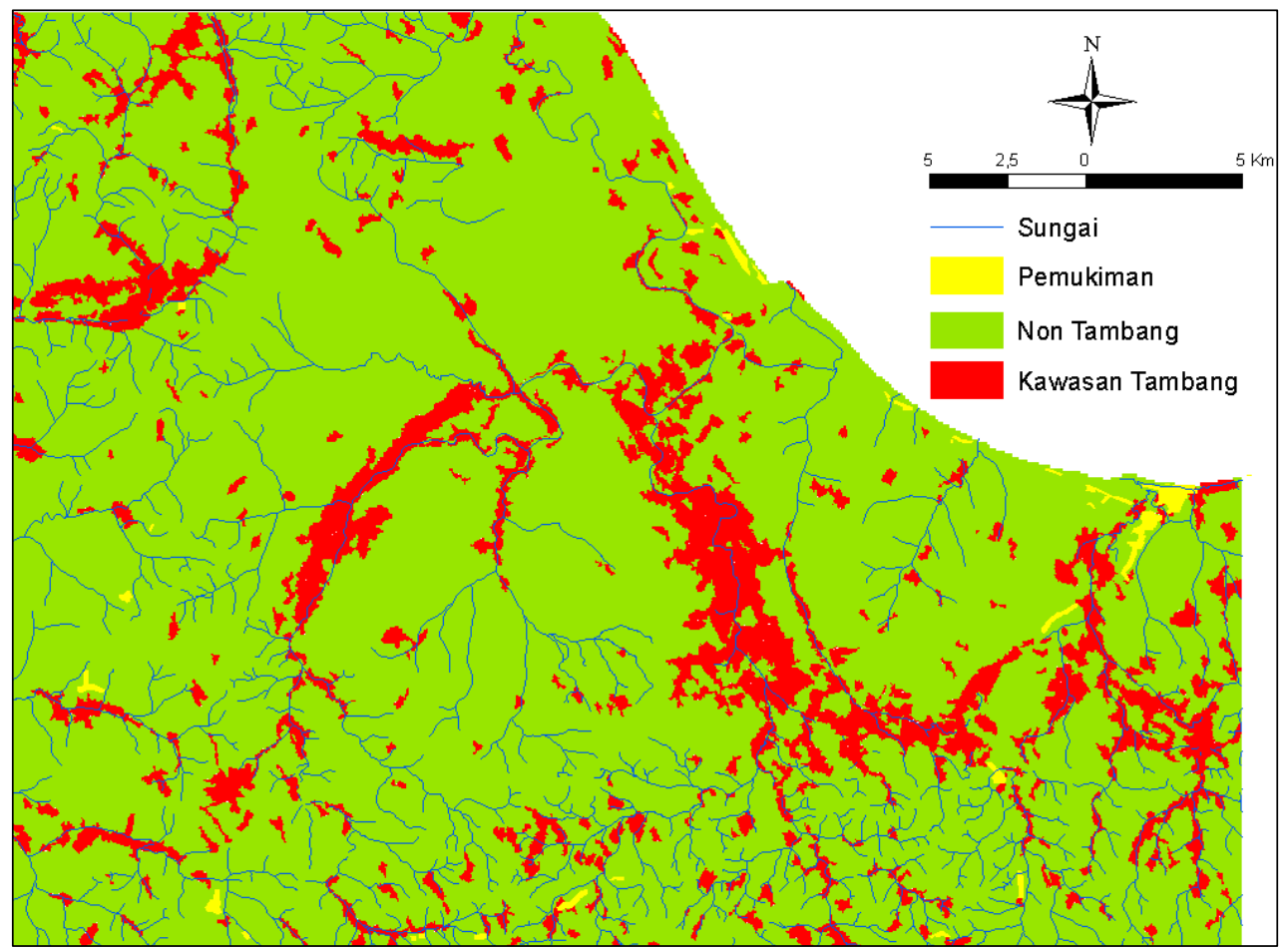

Gambar 5. Overlay pola aliran dan pemukiman dengan kawasan pertambangan

Berdasarkan hasil klasifikasi, dapat dilihat bahwa daerah pertambangan banyak terdapat di sekitar pola aliran sungai. Kegiatan penambangan yang dilakukanmenyebabkan perubahanlingkungan, melakukan kegiatanpenambangan yang tidak sesuai denganperuntukannya seperti melakukankegiatan penambangan di DAS (DaerahAliran Sungai), kawasan hutan lindungmaupun konservasi yang berakibat padabanjir (Yuliana, 2017). Pada Gambar 5, terdapat 16 titik kawasan permukiman, yang ditunjukan dengan warna kuning, di sekitar sungai yang terdapat aktivitas pertambangan. Hal ini perlu menjadi perhatian sebagai daerah yang rawan untuk terpapar air asam yang terdapat di genangan galian tambang atau biasa di sebut kolong dan juga rawan menjadi korban bencana banjir. Air asam tambangberpotensi mencemari air permukaan danair tanah. Tailingmengandung logam-logam berat seperti tembaga, timbal atau timah hitam,merkuri, seng, dan arsen. Ketika logam berat tersebut masukkedalam tubuh makhluk hidupakanterakumulasi di dalam jaringan tubuh dandapat menimbulkan efek 
yangmembahayakan kesehatan(Pirwanda dan Pirngadie, 2016).Menurut penelitian yang dilakukan oleh Sari (2016), kadar total timbal (Pb) tanah dilahan bekas tambang timah telah melewatibaku mutu. Rerata kadar total $\mathrm{Pb}$-tanah tertinggi terukur dilahan bekas tambang timah yang sudah direklamasi, yaitu $50.53 \mathrm{ppm}$.

\section{Kesimpulan}

Data satelit radar Sentinel -1 berpotensi digunakan untuk mengidentifikasi kawasan pertambangan timah. Hasil klasifikasi berdasarkan OBIA dengan algorithma klasifikasi nearest neighbor menunjukan bahwa data teksur GLCM dapat meningkatkanakurasi sebanyak 0,3\% dan nilai kappa 0,2 dibandingkan dengan hasil klasifikasi yang tidak menggunakan tekstur GLCM. Hasil klasifikasi kawasan pertambangan dapat digunakan sebagai masukan awal dalam rangka identifikasi spasial kerusakan lingkungan akibat aktivitas pertambangan.

\section{UCAPAN TERIMA KASIH}

Penulis mengucapkan terima kasih kepada Pusat Pemanfaatan Penginderaan Jauh LAPAN atas dukungan fasilitas dan pendanaan atas penelitian ini serta kepada Pusat Teknologi dan Data Penginderaan Jauh LAPAN atas dukungan data citra satelit yang digunakan pada penelitian ini.

\section{DAFTAR PUSTAKA}

Arief, M., Roswintiarti, O., Julzarika, A., Hawariyyah, S., \& Prayogo, T. (2010). Inventarisasi Tutupan Lahan Menggunakan Satelit Penginderaan Jauh Alos Dengan Metode Klasifikasi Tetangga Terdekat Study Kasus: Jawa Barat. Majalah Sains Dan Teknologi Dirgantara, 5(4), 174-182.

Affan, M., Faizah, \& Dahlan. (2010). Land Cover Change Analysis Using Land Cover Change Analysis Using Satellite Images. Jurnal Natural. 10(1): 50-55

Albregtsen, F. (2008). Statistical texture measures computed from gray level coocurrence matrices. Image processing laboratory, department of informatics, university of oslo, 5.

Badan Pusat Statistik. (2017). Pendapatan Nasional Indonesia 2013 - 2017. Jakarta: Badan Pusat Statistik

Bainnaura, A. (2010). Aplikasi Citra Alos Palsar Resolusi 50 M Dan 12,5 M Untuk Identifikasi Tutupan Lahan (Studi Kasus: Kabupaten Bogor Dan Sukabumi (Skripsi). Institut Pertanian Bogor : Bogor

Bamford, T., Esmaeili, K., \& Schoellig, A. P. (2017). A real-time analysis of post-blast rock fragmentation using UAV technology. International journal of mining, reclamation and environment, 31(6), 439-456.

Blaschke, T. (2010). Object based image analysis for remote sensing. ISPRS Journal of Photogrammetry and Remote Sensing, 65 (1),2-16

Blaschke, T., \& Hay, G. J. (2001). Object-oriented image analysis and scale-space: theory and methods for modeling and evaluating multiscale landscape structure. International Archives of
Photogrammetry and Remote Sensing, 34(4), 2229.

Burnett, C., \& Blaschke, T. (2003). A multi-scale segmentation/object relationship modelling methodology for landscape analysis. Ecological modelling, 168(3), 233-249.

Cazals, C., Rapinel, S., Frison, P. L., Bonis, A., Mercier, G., Mallet, C., Corgne, S., dan Rudant, J. P. (2016). Mapping and Characterization of Hydrological Dynamics in a Coastal Marsh Using High Temporal Resolution Sentinel-1A Images. Remote Sensing 8(7), 570

Emiyati, Manoppo, A. K., \& Hartuti, M. (2016). Pemanfaatan Data Radar Sentinel 1 untuk Pemetaan Lahan Tambak di Kabupaten Gresik Jawa Timur. Prosiding Seminar Nasional Penginderaan Jauh. Depok: LAPAN.

ESA (European Space Agency). (2013). Sentinel-1 User Handbook. European Space Agency Technical Note. European Space Agency (ESA). https://doi.org/10.1017/CB09781107415324.00 4

Gan, G., Ma, C., \& Wu, J. (2007). Data clustering: theory, algorithms, and applications (Vol. 20). Siam : Philadelphia

Haralick, R. M., Shanmugam, K., dan Dinstein, I. (1973). Textural Feature for Image Classification. IEEE Transactions on Systems, Man and Cybernetics, 3(6), 610-621

Kasim, A. A., \& Harjoko, A. (2014). Klasifikasi citra batik menggunakan jaringan syaraf tiruan berdasarkan gray level co-occurrence matrices (GLCM). Prosiding Seminar Nasional Aplikasi Teknologi Informasi (SNATI) (Vol. 1, No. 1).

Kushardono, D. (2012). Klasifikasi Spasial Penutup Lahan Dengan Data Sar Dual-Polarisasi Menggunakan Normalized Difference Polarization Index Dan Fitur Keruangan Dari Matrik Kookurensi (Spatial Land Cover Classification Using Dual-Polarization Sar Data Based On Normalized Difference Polarization Index And Spatial Features From Co-Occurrence Matrix). Jurnal Penginderaan Jauh dan Pengolahan Data Citra Digital, 9(1).

Lutfi, M., \& Antono, H. T. (2011). Estimasi Biomassa Hutan Sekunder Dan Daerah Reklamasi Menggunakan Teknologi Inderaja Dan Sistem Informasi Geograf. Jurnal Teknologi Mineral Dan Batubara, 7(2), 54- 230. https://doi.org/10.1017/CB09781107415324.00 4

Miranda, N., Meadows, P. J. (2015). Radiometric Calibration of S-1 Level-1 Products Generated by the S-1 IPF. Viewed at https://sentinel. esa. int/documents/247904/685163/S1-

Radiometric-Calibration-V1. 0.pdf

Nugroho, U.C., Susanto, S., Yudhatama, D., \& Mukhoriyah, M. (2015). Identifikasi Lahan Tambang Timah Menggunakan Metode Klasifikasi Terbimbing Maximum Likelihood Pada Citra Landsat 8. Majalah Ilmiah Globe, 17(1), 09-15.

Nurtjahya, E. (2008). Revegetasi lahan pasca tambang timah dengan beragam jenis pohon lokal di Pulau Bangka [Disertasi]. Institut Pertanian Bogor : Bogor

Pirwanda, F., \& Pirngadie, B. (2018). Dampak Kegiatan Tambang Timah Inkonvensional Terhadap 
Perubahan Guna Lahan Di Kabupaten Belitung. Jurnal Planologi Unpas, 2(3), 177-194.

Sari, E., Giyanto, G., \& Sudadi, U. (2018). Acacia Auriculiformis Dan Eragrostis Chariis: Vegetasi Potensial Dari Lahan Bekas Tambang Timah Pulau Bangka Sebagai Fitoremediator Pb Dan Sn. Jurnal Ilmu Tanah dan Lingkungan, 18(1), 1-7.

Sari, N. M., \& Kushardono, D. (2014). Klasifikasi Penutup Lahan Berbasis Obyek Pada Data Foto Uav Untuk Mendukung Penyediaan Informasi Penginderaan Jauh Skala Rinci (Object Based Classification Of Land Cover On Uav Photo Data To Support The Provision of Detailed-Scale Remote Sensing Information). Jurnal Penginderaan Jauh dan Pengolahan Data Citra Digital, 11(2).

Sutanto, A., Trisakti, B., \& Arimurthy, M. (2014). Perbandingan Klasifikasi Berbasis Objek dan Klasifikasi Berbasis Piksel Pada Data Citra Satelit
Synthetic Aperture Radar Untuk Pemetaan Lahan. Jurnal Penginderaan Jauh, 11(1), 63-75.

Tjhiaw, G. dan T.S. Djohan. (2009). Suksesi Vegetasi Alami di Bekas Tambang Timah Pulau Bangka. Manusia dan Lingkungan, 16, 23-41.

Wibowo, T. S., \& R Suharyadi, R. S. (2012). Aplikasi Object-Based Image Analysis (OBIA) untuk Deteksi Perubahan Penggunaan Lahan Menggunakan Citra ALOS AVNIR-2. Jurnal Bumi Indonesia, 1(3).

Yuliana HS. (2017). Analisis Dampak Pertambangan Timah Rakyat Terhadap Bencana Banjir. Jurnal Manajemen Bencana, 3 (1), 57 - 73.

Zylshal, Z., Susanto, H., \& Hidayat, S. (2016). Ekstraksi Informasi Penutup Lahan Area Luas Dengan Metode Expert Knowledge Object-Based Image Analysis (Obia) Pada Citra Landsat 8 Oli Pulau Kalimantan. Majalah Ilmiah Globe, 18(1), 09-20. 